\title{
Design of Digital Based Volley Ball Basic Techniques Test Instrument
}

\author{
Asep Suharta ${ }^{1}$, Amir Supriadi $^{2}$, Nurkadri ${ }^{3}$ \\ ${ }^{1,2,3}$ Faculty of Sports Science, Universitas Negeri Medan, Indonesia \\ asep_suharta@yahoo.com,amirsupriadidr@gmail.com,nurkadri@unimed.ac.id
}

\begin{abstract}
This study aims to design a digital-based volleyball basic technical skill test instrument using internet technology as its application. This study uses a research and development design method (Research and Development) used in this study is the Borg and Gall development model with 7 steps of potential problems, data collection, product design, product validation, design revision, product trial, product revision, trial usage, product revision, and production. This learning product was developed in the design of a digital-based volleyball basic technique test instrument. The products of this research are 1) produce a basic volleyball technical test instrument application product used in smartphones, 2) produce a villi ball basic technical instrument product that is easily accessible via the internet. From the results of a small-scale trial conducted on 10 students of the sports coaching education study program (PKO) with a percentage obtained of $83 \%$ in the "Eligible" category, and from the results of a large-scale trial of 15 students of the health and recreation physical education study program ( PJKR) and sports science prosi (IKOR) with a percentage obtained of $84 \%$ in the "Eligible" category. It can be concluded that the digital-based volleyball basic technical skill test instrument developed by the researcher can be used.
\end{abstract}

\section{Keywords}

test instrument; basic technique; volleyball; digital

\section{Introduction}

The development of digital technology has penetrated all aspects of life, including the education aspect. The rapid development of technology in the era of the industrial revolution 4.0 is very influential on the methodlearning in various schools and colleges. In learning in the era of digital technology, skills and competencies are the main things that need to be considered. Because in the era of the industrial revolution 4.0, the integration of the use of technology and the internet is so sophisticated and massive. Several challenges arise in facing the industrial era in universities in Indonesia. This challenge is not an obstacle but a driving force for digital use. Universities in Indonesia have developed many learning tools that use digital media.

In this digital era the development of technology is developing very rapidly. This is because the world entered industry 4.0 where technology became the most basic thing in it. When the world undergoes a changing era, there are many things that also follow it or in other words, changes occur in several sectors of life. However, it is not just the changes that occur but the challenges go along with it. Angela Merkel (2014) argues that Industry 4.0 is a comprehensive transformation of all aspects of production in the industry through the merger of digital technology and the internet with conventional industries. It can be said that the 4.0 industrial revolution is based on digital. The development of technology and information has brought the current generation into the world of digital literacy. The digital age has become one with the current condition of society. This condition has caused 
many people to be easier, faster and have greater opportunities in finding various information. In addition, one of the benefits of information technology is being able to overcome the limitations of space and time. Workers in all fields during the Industrial Revolution 4.0 era are required to have digital skills, such as in the fields of development, economics and in education. In the field of education for example, an educator must understand digital mastery. Various kinds of technology should be applied in teaching in the classroom. (Sagita and Khairunisa, 2020)

Likewise, the State University of Medan (Unimed) feels a positive impact in this digital era. This encourages Unimed to implement an innovative learning system in a network called an Online Information System (SIPDA). This e-learning system is adapted to the latest technological developments. Its use aims to speed up the learning process. Unimed continues to encourage lecturers to use the latest learning in accordance with the latest technological developments. This is to answer the needs of the digital community that is all practical and easy to access information. Furthermore, lecturers at Unimed, including Lecturers at the Faculty of Sports Science (FIK) have made many developments in terms of learning methods, teaching materials that refer to digital learning. However, it has not been widely used for evaluating student learning. Edy (2017:28) emphasizes the importance of learning evaluation by stating that evaluation can be done to determine student learning outcomes, the effectiveness of educational programs, and the internal conditions of universities (self-evaluation).

The distribution of courses in the FIK curriculum consists of theoretical and practical courses in sports. One of the practice courses in sports, including the volleyball course. Volleyball is a compulsory subject for three study programs, namely Physical Education, Health and Recreation (PJKR), Sports Coaching Education (PKO), and Sports Science (IKOR) at the Faculty of Sports Science (FIK) Medan State University (Unimed). Practical lectures are given for mastery basic movements and basic technical skills in volleyball games. The basic movements of the volleyball game include locomotor, non-locomotor movements and their combinations both with and without the ball. The basic techniques in the volleyball game include the underhand passing technique and the service fload, the overhand technique, the smash technique, the block technique, the underhand service technique and the service technique.

The competency standards of volleyball courses are: Students are able to master and practice basic skills in volleyball games properly and correctly, namely: 1) Students are able to master and practice basic movements in volleyball games, 2) Students are able to master and practice basic techniques in volleyball games ( covering the technique of passing down receive service fload, technique of passing over, technique of smash, technique of block, technique of underhand service and technique of tennis service). This is in line with Harini, et al (2018: 125) that mastering basic techniques is the basis for improving skills in playing volleyball well.

The achievement of competency standards in this course is carried out through an assessment process. Assessment and evaluation is the most important part in learning, especially in basic volleyball technical material. Furthermore, some basic volleyball techniques are proposed by Ahmadi (2007:20) namely serve, passing, block, and smash. Through assessment and evaluation, accurate information can be obtained about the implementation of the learning process and the learning success of students, lecturers, and the learning process itself. For this reason, lecturers should have the ability to carry out learning evaluations as well as be able to develop evaluation tools in the form of good tests in measuring the achievement of learning objectives in volleyball subjects. 
Based on the results of observations in the assessment process of basic volleyball techniques, the assessments carried out by the lecturers in the three study programs still use assessments based on standard test references for volleyball basic techniques $b$. The implementation of the test assessment is carried out on the results of skill achievement. Furthermore, assessment measuring tools tend to use norm references. The assessment carried out ignores the mastery of the correct technique. This is contrary to the competency standards that have been determined previously.

Assessment should be used as an attempt to improve an appearance. Therefore, good information is needed and must be valid and reliable, because of the success of student learning in achieving predetermined competency standards. Responding to the development of digital technology, it is better if the assessment of basic volleyball techniques is carried out using digital technology.

Furthermore, a survey was conducted on a sample of students who took volleyball courses in the three study programs at FIK. As for the survey results, $80 \%$ of students stated that they were not satisfied with the assessment using the norm reference. $90 \%$ stated that they did not know what motion processes needed to be improved on the basic technical assessment carried out by the lecturer. And 100\% stated that they accepted that the assessment was done digitally because it would provide easy access to the results of the assessment.

To overcome these problems, it is necessary to find solutions with innovative breakthrough instruments that can provide accurate data on the implementation of basic volleyball technical tests. The use of digital media on the basic technical instrument of volleyball as an instrument to facilitate lecturers in processing grades, because it can be corrected in calculations directly while students immediately get feedback from the results of the tests carried out. For this reason, a digital-based volleyball basic technique test instrument was designed. . Digital-based is the use of technology in the field of sports, in this case the researcher uses a smartphone as a tool to assess through test instruments that have been inputted into the smartphone. A smartphone is a multifunctional cell phone that combines several functions of a PDA, such as a personal scheduler, calendar and phone book. A smartphone is equipped with the ability to access the internet, chat, instant messenger, social networking applications, GPS, e-mail, play online games, play music, videos, take pictures, record sound, to write and edit spreadsheet documents such as word files, powerpoint, pdf and excel. Chuzaimah, et al 2010:315) states that smartphones are designed and work through an operating system, where users can freely add applications, add functions or change according to the user's wishes like a computer in the hand. Smartphone is a mobile phone technology that has continued to develop since its inception and will continue to experience various innovations to meet communication needs. Smartphone is an android operating system that provides open source (open source). According to Nasruddin (2012: 1) Android is an operating system on mobile phones that is open and based on the Linux operating system. Android can be used by anyone who wants to use it on their device. This is because people's consumption patterns at this time always want an ease of communication that can support their daily activities both at work and in other matters. Communication needs, access to information and entertainment are met with an Android-based smartphone. This is in accordance with the opinion of Burnette (2009: 12) Android is a new open source software toolkit for future mobile devices, Android itself was created by the Google company in collaboration with the Open Handset Alliance.

The development of a digital-based volleyball basic technical skill instrument is carried out in several stages. This is in accordance with the opinion of Hadjar (1996:1) Several stages must be passed, namely 1) defining variables, 2) describing variables into 
more detailed indicators, 3) compiling items, 4) conducting trials, 5) analyzing validity. (validity) and reliability (reliability). The stages of instrument development are also stated by According to Arifin (2012) in general the test can be developed through the following stages: 1) determining the purpose of the assessment, 2) compiling a grid, 3) developing a draft instrument, 4) testing and analyzing questions, and 5) revision and assembling questions (new instruments). Another opinion was expressed by Sugiyono (2008:95) that the instrument is a tool used to measure the observed natural and social phenomena. Furthermore, the test that will be developed in this study is a test of the basic technical skills of volleyball games in the form of observation. Furthermore, Riduwan (2011) observation or observation is a technique or method of collecting data by observing ongoing activities. The skill test instrument developed requires internet access to open the instrument through the android system, Turban, Rainer, Potter $(2006 ; 69)$ "The Internet is a global system of computer networks, a network for various networks; cooperative and selfsustaining public facilities accessible to hundreds of millions of people around the world.

Based on the opinions of the experts above, it can be concluded that the steps of instrument development basically include planning, preparation, theoretical testing, instrument revision, empirical testing and assessment of measurement results. The use of this instrument makes it easy for lecturers, because it is applied via mobile phones so it is easy to carry anywhere. In addition, the use of technology through Android in measuring basic volleyball technical skills tests is expected to be able to answer challenges in the era of the industrial revolution 4.0 .

\section{Research Methods}

The research method used is a development research method with a qualitative approach. Development research is not to create theory or test theory but to develop a digital-based volleyball basic skill test instrument product. . The research subjects in this study were students of the Faculty of Sports Science. For the small group trial consisting of 10 students of the Sports Coaching Education Study Program (PKO). The large group trial consisted of 15 students from two study programs, IKOR and PJKR.

The data of this study were collected through qualitative and quantitative descriptive data. Qualitative data in the form of written interviews with input, suggestions, and responses from validators of experts, practitioners, observers and students. This type of quantitative data is obtained from the assessment scores given by validators, practitioners, observers, and students through validation activities and field trials. The data obtained are described in detail to determine the level of validity, practicality, and effectiveness of digital-based assessment instruments of volleyball basic techniques.

The development method used in this research is the Borg and Gall development model with 7 steps. This was done due to time and cost constraints. This is supported by Sukmadinata (2015) which states that development research can be stopped until a final draft is produced, without testing the results. The results or impacts of the implementation of the development of movement activities already exist in small group trials and large group trials. The 7 steps are explained as follows: 1) Conducting preliminary research (presurvey), 2) planning, 3) product drafting, 4) initial testing, 5) revising the product, 6) Conducting field trials, 7) Conducting product revision. 


\section{Results and Discussion}

The results of this study can be used to increase the effectiveness of the assessment process for student learning outcomes in digital-based volleyball lectures. With the development of this instrument, it makes it easier for students to do remedial and enrichment in achieving mastery in learning. Furthermore, this product can be used in schools in the subjects of Physical Education, Sports and Health, other universities outside the Unimed area which has a Faculty of Sports Science, Volleyball Clubs for beginner athletes in North Sumatra. This research was carried out with the aim of providing a solution in conducting a volleyball game skill test. The stages of developing the developed tool are named "Design of Volleyball Basic Technique Test Instruments". The steps taken in this research are as follows:

\subsection{Needs Analysis}

Needs analysis in the preparation of the instrument is needed to develop and explore the problems of the basic volleyball technical skills test for students. This activity is carried out by analyzing the lecture process in the field, making observations, and conducting literature studies / literature reviews

The product draft of the volleyball basic technique test instrument that was produced included: (1) the draft of the volleyball basic technique test instrument for students, (2) the validity and reliability of the volleyball basic technique instrument for students, (3) the points of the technical test instrument the basis of digital-based volleyball for students that is valid for dissemination to become a final instrument. After determining the product to be developed, the next step is to make a basic volleyball technical test instrument product for students.

\subsection{Initial Product Draft Expert Validation}

The initial product of the digital-based volleyball basic technique test instrument design before being tested in a small group test was validated by experts in accordance with the research field. To validate the product to be produced, the researchers involved three (3) volleyball experts who also mastered the field of physical education from lecturers, and electronics experts. Furthermore, validation is done by providing an initial product draft, with a dissertation evaluation sheet for experts. The evaluation sheet is in the form of a questionnaire containing aspects of the quality of the initial test instrument, the design of the digital-based volleyball basic technique test instrument and suggestions and comments from experts. The evaluation results in the form of scores for the quality aspect using a Likert scale of 1 to 4 . The data obtained from filling out questionnaires by experts, is a guide for stating whether the product of the initial instrument design design of the digital-based volleyball basic technique test instrument can be used for small-scale trials and wide scale. The empirical data calculation can be seen in table 1, namely the validation assessment table for volleyball game experts.

Table 1. Expert Validation Calculation Results

\begin{tabular}{|c|c|c|c|c|}
\hline Ahli & $\begin{array}{c}\text { Jumlah } \\
\text { Jawaban }\end{array}$ & $\begin{array}{c}\text { Skor } \\
\text { Maksimal }\end{array}$ & P \% & Kategori \\
\hline Ahli Bola Voli & 42 & 60 & 70 & Layak \\
\hline Ahli Akademisi & 44 & 60 & 73,3 & Layak \\
\hline Ahli IT & 24 & 35 & 68.6 & Layak \\
\hline
\end{tabular}


Based on the results of Table 1, it can be seen that volleyball experts with a percentage obtained are $70 \%$ in the "Eligible" category, sports academic experts through the results of calculations with a percentage obtained are $73.3 \%$ in the "Eligible" category and IT experts provide an assessment with a percentage of the calculation results. of $68.6 \%$ in the "Eligible" category, so it can be concluded from the three experts who became validators in this study were in the "Eligible" category.

After the product design of the digital-based volleyball basic technical instrument was validated by experts and revised, then a small-scale trial was carried out on 10 students of the Faculty of Sports Science of the PKO study program, which can be seen in table 1.1. below this.

Table 2. Test Results Hasil

\begin{tabular}{|c|c|c|}
\hline Respondent & Answer & Percentage\% \\
\hline 1 & 12 & 80 \\
\hline 2 & 13 & 86 \\
\hline 3 & 12 & 80 \\
\hline 4 & 12 & 80 \\
\hline 5 & 14 & 93 \\
\hline 6 & 13 & 86 \\
\hline 7 & 11 & 73 \\
\hline 8 & 12 & 80 \\
\hline 9 & 13 & 86 \\
\hline 10 & 13 & 86 \\
\hline \multicolumn{2}{|c|}{} \\
\hline
\end{tabular}

Based on these results, the design of the digital-based basic movement skills test instrument that was developed from the physical and design aspects was categorized as "fairly feasible". With a value of $83 \%$.

This development research is carried out through stages starting from seeing potential problems, collecting information, designing products, validating, revising products, conducting trials, and making final products. The expert validation stage is carried out in two stages. The first stage was used as the basis by the researchers to revise the deficiencies that existed in the developed tool. When validating, the first stage volleyball game experts suggested that the process of basic technique assessment indicators be made simpler so that it was easier to observe volleyball basic motion techniques.

The first stage of validation is used as the basis for improving the tools being developed. When validating, electronic experts advise that the domain is made simpler because the basic technique is simple and a score criterion is given so that the results can be quickly seen by the rater

After going through product trials, the advantages and disadvantages of this research can be described. The advantages of the digital-based volleyball basic technique test instrument design are (1) easy and practical use (2) provides (2). Easy to apply on android phones,(3). Simple technology can support the ease in the process of assessing volleyball basic technical tests.

Meanwhile, the drawbacks of designing a digital-based volleyball basic technique test instrument are as follows: (1). There are still a few basic technical components assessed, (2). Must use internet network. The products from the development carried out can be seen in.http://instrumenbvrade-fikunimed.com 


\section{Conclusion}

The conclusions of this study are as follows.

1. In expert validation 1 volleyball game, the percentage results obtained have increased from $70 \%$ to $75 \%$ of the maximum score in the "decent"\% category.

2. In expert validation 2 volleyball games, the percentage results obtained have increased from $73.3 \%$ to $76.7 \%$ of the maximum score in the "decent" category.

3 . In the validation of electronics experts, the percentage obtained has increased from $68.6 \%$ to $77.14 \%$ of the maximum score in the "adequate" category.

4. The design of the digital-based volleyball basic technique test instrument is feasible to be used as a volleyball basic technique test instrument.

\section{References}

Ahmadi.N. (2007). Panduan Olahraga Bolavoli. Surakarta: Era Pustaka Utama.

Arifin, Zaenal. (2012). Evaluasi Pembelajaran. Bandung: Rosda Karya.

Burnette, E.(2009). Hello, Android introducing Google's mobile development platform 2nd.

Edy Supriyadi. (2017). Pengembangan Model Evaluasi Untuk meningkatkan mutupendidikan teknik Elektro. Jurnal Edukasi Elektro, Vol.1, No 1...hal.25-35.eISSN : 2548-8260 http://journal.uny.ac.id/index.php/jee/.

Chuzaimah Mabruroh, Fereshti Nurdiana Dihan.2010. Smartphone: Antara kebutuhan dan life style.Seminar Nasional Informatika. Vol 1, No 5 ).

Harini Anggara, Agus Kristiyanto, Siswandari. (2018). Part Whole Part and Whole Part Whole Affect Volley Normal Smash Ability. Journal of Physical Education, Sport, Health and Recreations.h.124-127. p-ISSN 2460-724X. e-ISSN 2252-6773.

Ibnu Hadjar. (1996). Dasar-dasar Metodologi Penelitian Kuantitatif dalam Pendidikan. Jakarta: Raja Grafindo Persada.

Riduwan. 2011. Belajar Mudah Penelitian. Alfabeta : Bandung.

Safaat,Nazruddin h. 2012. " Pemrograman Aplikasi Mobile Smartphone dan Tablet PC berbasis android, Cetakan Pertama, Edisi Revisi, Penerbit Informatika Bandung.Bandung

Sugiyono. 2008. Metode Penelitian Pendidikan P

Sagita, M and Khairunisa. (2020). E-Learning for Educators in Digital Era 4.0. Budapest International Research and Critics Institute-Journal (BIRCI-Journal). P. 1297-1302.

Sugiyono. (2008). Metode Penelitian Pendidikan Pendekatan Kuantitatif, Kualitatif, dan R \& D. Bandung : Alfabeta.

Turban, Rainer, Potter ( 2006 ), Pengantar Teknologi Informasi . Salemba Infotek . Jakarta Witono Hidayat. (2017).Buku Pintar Bola Voli. Jakarta.Anugerah. 